\title{
Innovative development opportunities for construction enterprises in the context of global challenges
}

\author{
Ekaterina Acri ${ }^{1}$, Anna Kornilova ${ }^{2}$, Zhanna Selezneva ${ }^{1}$, and Natalia Solopova, ${ }^{3, *}$ \\ ${ }^{1}$ Samara State Technical University, Molodogvardeyskaya str, 194, 443001, Samara, Russian Federation \\ ${ }^{2}$ Samara State University of Economics, Soviet Army str, 141, 443090, Samara, Russian Federation \\ ${ }^{3}$ Moscow State University of Civil Engineering, National Research University, Yaroslavskoye Shosse, 26, 129337 Moscow, Russian \\ Federation
}

\begin{abstract}
The specifics of industrial enterprises' functioning in the construction sector of the Russian economy are of particular interest and have been a subject of active discussion over the past years. This article analyzes functioning of the construction complex companies in the context of new global challenges associated with the crisis phenomena in 2020 - the fall in oil prices and the coronavirus infection, as well as the transition to remote operation during the pandemic of basic economic branches. Nowadays, it is especially important to assess reserves for sustainable innovative development of industrial enterprises and predict consequences of the crisis phenomena. The authors investigate some organization forms for the innovative process, determine key efficiency factors of enterprises' innovative activity and propose ways for its improvement.
\end{abstract}

\section{Introduction}

Under conditions of new global challenges in the market environment, the industrial enterprises' development and their functioning are influenced by the innovation mechanism and applied innovations. The significance of innovations and innovative activity for industrial enterprises is constantly increasing in modern conditions. At present, the external and internal market exerts certain pressure on various enterprises. This pressure is reflected in the development of new markets for goods and services, changes in the consumer behavior, the global development of new technologies of various types and, as a result, increased competition.

Each enterprise experiences high risks launching a new product or applying a new technology [1]. The risk level may be different and it is often influenced by the novelty degree of a product or the applied technology. The uncertainty of market perception of a new product and the novelty degree of goods and services are mutually interdependent. In this context, we can classify uncertainty types in different ways taking into account that all of them affect the efficiency of innovative process [2]. Innovations in the construction industry may help to overcome some economic risks. Participants of the innovative process touch through their activities interests of the whole management hierarchy not only in one specific economy branch, where the innovative product is developed and created, but also in industries that are consumers of these innovations, branches that provide resources (technology, energy and others) [3].

Innovations present a new way to satisfy needs. Innovative products are traditionally associated with quality, comfort and efficiency. On the one hand, they work for a qualitative efficiency increase in the company, serve as a tool ensuring the high quality of a product or the whole production system, the competitiveness of the company. Innovations usually imply the use of the latest scientific achievements and best world practices [4]. Due to the use of innovations, enterprises manage to develop new entrepreneurial culture, get new product types, technology lines, management and work styles.

To determine the essence of the enterprise's innovative potential, we usually try to describe innovative capabilities of this company, its unique resources, and competitive advantages. The innovative potential also allows achieving goals with minimal risks through the implementation of projects. The description of innovative potential influences the choice of a strategy that can be understood as readiness to reach the set goals in the field of innovative development of the enterprise [5].

\section{Methodology}

The methodological basis of this research is a systematic approach that allows us to consider the innovative activity of the research object, which consists of many elements. The following research methods were used: formal-logical (deduction, induction, justification, and argumentation); abstract-logical (when setting goals, research tasks that justify a working hypothesis); empirical (observation and experimentation); economicstatistical (identification of risks in innovation),

* Corresponding author: ushanovan@mail.ru 
economic-mathematical. Data processing was performed using the Microsoft Office software package (Excel, Word).

The purpose of the article is to consider some development problems of the construction complex in the Russian Federation. It's worth noting that the main task of the state innovative policy is to apply new perspective technologies of economic sectors, ensuring the competitiveness of domestic industry taking into account the declared priority goals for of the further development of the country, and helping to overcome the crisis in the construction sector.

With the formation of the innovation economy type, the structure of the construction complex influences the investment flow in the regional economy to improve the competitiveness of the complex in the global market. Investments in construction are also dependent on implemented innovative projects in related industries, decisions made by the state and municipal authorities, actions by enterprises themselves, as well as ways and tools of innovative development. The construction branch is a sphere that enables efficient solutions of some basic economic and social issues. The development level of this industry determines essential prospects for formation, development and technical re-equipment of the economy. Problems that this industry enables to solve relate to the state and efficient functioning of the national economy, the quality of life of the population.

\section{Results}

This economic situation in 2020 caused a significant damage to business in the construction complex in the form of a sharp drop in demand for industrial (office and retail) real estate. The industrial experience of remote work in various business areas gained during the pandemic is likely to continue in the "quiet" time. Certain categories of employees will switch to flexible remote operation. Due to forced self-isolation, the dynamics of sales growth by means of online trading will start to increase at a galloping pace in the near future.

Sustainable functioning of organizations in current economic, ecological and social conditions is impossible without changes in basic elements that determine the enterprise model. It relates to organizational structure, applied technologies and any other aspects that form the enterprise's competitiveness. An important role in this process belongs to innovations. Organization's innovative activity is a complex of actions aimed at the improvement of product or work quality and the development of a range of additional services trough innovations. This activity type also means in case of construction enterprises the development of used technologies and increase in the company efficiency (Figure 1).

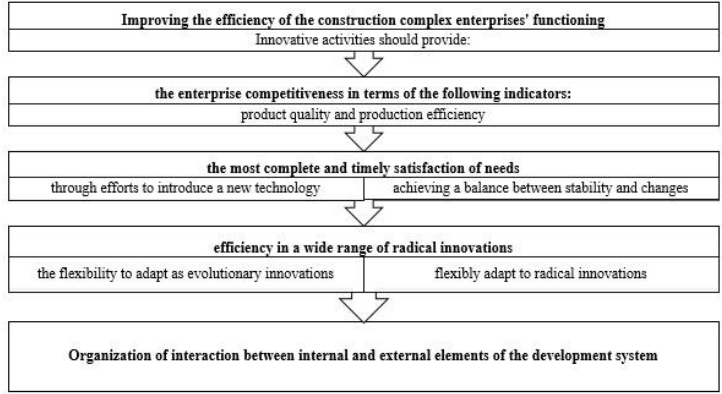

Fig. 1. Efficiency of construction complex enterprises: improvement issues (Source: compiled by the authors).

The innovative activity is aimed at creating new markets, technologies, products or services. It is carried out in a certain environment. That means that direction, pace, and goals of innovative activity depend on the nature and development trends of the socio-economic space where the company operates.

One of the key factors determining the company's innovative activity is time. It is quite important to understand that absolutely all products types become out of date one day. This forces businesses to conduct analysis of the own products, used technologies, the external and internal environment. It is also needed to systematically evaluate market and distribution channels [6]. It should be noted that innovations bring real benefits to their manufacturer over a given period of time. The concept of the innovation life cycle plays an essential role in management of innovations. To be able to innovate, businesses need to have a certain structure and mindset that helps create an favorable environment for new opportunities.

\section{Discussion}

Infrastructural development of cities, rural settlements and metropolitan areas, housing condition, safety and environmental friendliness of buildings, comfort and harmonious life of people, the level and quality of life are largely determined by the performance of the construction sector of the economy, which is an innovative development generator for many related industries and a major point of growth for socioeconomic development of the whole state [7].

Currently, the construction, housing and utilities sectors are fundamental branches in the national economy, accounting for a total of about $17 \%$ of the Russian GDP. The construction sector traditionally employs more than $10 \%$ of the country's working population. The architectural and construction complex largely determines the quality and technical level of objects being built, and significantly affects the economy of the state as a whole, its power and defense capabilities.

At the beginning of 2020, the world was hit by an unprecedented drop in global oil prices and the spread of coronavirus infection. This caused a downturn in both the Russian economy and the construction sector. A recession phase of the Russian economy is almost inevitable, with all the resulting negative consequences 
for manufacturing enterprises, for the labor market, and for basic social indicators such as unemployment, real incomes, inflation, interest rates on loans, etc.

In the real situation of 2020 , the position of the economic activity "Construction" is quite difficult to predict. Therefore, it is possible to build an estimated model for the development of the construction industry in the near future. Generalized seasonally-smoothed results of the market survey of the business climate for construction enterprises indicate a gradual improvement in the situation (Table 1).

Table 1. Estimates of the main performance indicators of construction organizations (balance sheet, \%) (Source: authors based on [8]).

\begin{tabular}{|c|c|c|c|c|}
\hline \multirow{2}{*}{ Indicator } & \multirow{2}{*}{\begin{tabular}{|c|}
2018 \\
I quarter
\end{tabular}} & \multicolumn{2}{|c|}{2019} & \multirow{2}{*}{$\begin{array}{c}2020 \\
\text { I quarter }\end{array}$} \\
\hline & & I quarter & IV quarter & \\
\hline The index of business confidence & -20 & -20 & -18 & -15 \\
\hline $\begin{array}{l}\text { Number of concluded } \\
\text { contracts }\end{array}$ & -7 & -1 & -6 & -3 \\
\hline Physical volume of work & -12 & -12 & +1 & -1 \\
\hline Number of employees & -14 & -14 & -10 & -8 \\
\hline $\begin{array}{c}\text { Prices for construction and installation } \\
\text { works }\end{array}$ & +36 & +43 & +43 & +45 \\
\hline Prices for construction materials & +67 & +72 & +68 & +67 \\
\hline $\begin{array}{l}\text { Provision with own financial } \\
\text { resources }\end{array}$ & -8 & -12 & -3 & -12 \\
\hline $\begin{array}{l}\text { Availability of borrowed financial } \\
\text { resources }\end{array}$ & -1 & -4 & -5 & -1 \\
\hline Investments & -2 & -5 & -6 & -7 \\
\hline
\end{tabular}

The total index of business confidence for the first quarter significantly moved away in a positive direction from the critical quarterly values typical for business opinions in the last four years, reaching the mark of ($15 \%$ ) for the first time.

Nevertheless, the increased mobilization of business activity has not reduced the scale of the negative dynamics of key production, financial and economic indicators accumulated over the past years. Most indicators of the business environment still indicate a relatively unfavorable situation in the construction industry and show a conservative, rather pinpoint dynamics of the ongoing corrective positive changes.

The prevailing trends in the production environment could not support the financial block of indicators, determining the strengthening of negative trends in most of them. Top managers' pessimistic moods regarding the assessment of organizations' own financial resources and investment potential have increased. At the same time, the situation was more favorable with the provision of organizations with credit and borrowed funds. Remaining within the downtrend, this indicator showed a noticeable slowdown in the decline and came close to the reversal point (the balance of the estimate rose to ($1 \%$ ) from $(-5 \%)$ in the fourth quarter of 2019$)$.

The formation of an inflationary background in the construction industry in the first quarter maintained moderate volatility. Despite the constraining factor in the form of the continuing trend of weak deceleration of price growth for construction materials, the emphasis in the dynamics of prices for construction and installation work was opposed and expressed in their accelerated growth compared to the fourth quarter of the last year. The share of companies whose managers raised their prices for SMR increased to 48 from $46 \%$.
Construction companies continue to be under pressure of the "lack of work orders" factor, which affected $27 \%$ of enterprises and organizations, although at the end of the fourth quarter of 2019, their share showed a decrease to $25 \%$ compared to the first quarter. At the same time, the level of customers' insolvency remained unchanged. In general, in the first quarter of $2020,7 \%$ of managers of industrial enterprises in the construction sector recorded a complete absence of restrictions for the financial, economic and production development of companies; in the first quarter of 2019, this share was only $4 \%$.

However, it can be noted that the current negative economic situation caused by the decline in world oil prices and the pandemic differs significantly from the crisis periods of 1998 and 2008. At the present time, there is not a financial or debt crisis, in which financial settlements between economic entities are significantly reduced, but we have an unprecedented drop in demand and supply in almost all types of the economic activity. Industries that are significantly dependent on consumer and investment demand for their products are more affected by such events (for instant, the construction industry). A decrease in demand for construction products will inevitably reduce the volume of construction work for developers themselves, which may lead to the bankruptcy of a number of enterprises, mainly with low financial stability, and to excessive monopolization of certain subjects of the construction market [9].

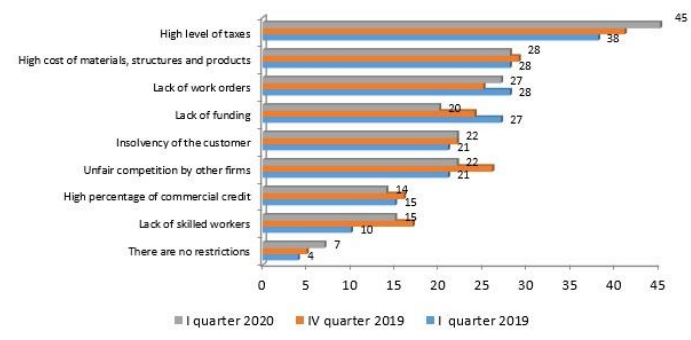

Fig. 2. Factors that restrict the production activities of construction organizations (the share of organizations from their total number, in \%) (Source: compiled by the authors based on [8]).

On the one hand, price problems will largely affect the construction industry, which produces building materials. The devaluation effect, which is associated with the fall of the national currency, will cause an increase in prices for products of the construction material and technical base industry due to the increase in the cost of imported equipment, components and used raw materials [10]. It is not known yet how China, the main foreign supplier of raw materials, will behave after all the tests that have befallen this country. On the other hand, this effect motivates domestic manufacturers to apply innovations and export manufactured building materials [11].

Implementation of innovations is often associated with risks, fails, and setbacks [12]. The typical causes are insufficient analysis of development trends of the external environment, opportunities and threats existing there, and misunderstanding of internal resources 
including production capabilities and own financial means, as well as. Analyzing the most common shortcomings and mistakes made by enterprises proposing their innovations to the market, we can conclude that the formation of conditions that are favorable for innovative development of enterprises is primarily determined by specifics of the management and production systems of a certain organization and in particular by the culture (or its absence) of innovative technologies implementation. To manage changes in the areas of production and management, the organization needs an integrated approach.

\section{Conclusion}

The problems faced by the global economy have put the construction industry in a difficult economic situation. Surely next year there will be an intensification of bankruptcy process of enterprises in this industry, increase in unemployment and decrease in productivity, increase in prices for construction enterprises' products and a possible reduction in the cost of housing projects, increased construction time and violation of the contractual terms of the financial settlement, the deterioration of the financial components because of the fall in the annual volume of performed work.

The way out of this situation will depend, first, on the rational actions of managers of construction enterprises, in particular, on the effectiveness of their use of new anti-crisis management schemes and innovative development, and secondly, on the operational and constructive actions of regulators on the part of the government, as well as on the intensity of negative economic and epidemiological processes.

As a result of research, construction companies are offered the following directions for achieving sustainable innovative development, which should include the following set of consecutive steps:

- develop, in accordance with the company's mission and strategy, a set of measures to improve the innovation processes currently taking place within the organization;

- ensure the availability of resources for the implementation of innovative projects by integrating innovation and investment activities;

- improve existing and develop new methods of management of innovative development of the enterprise with the most rational combination of operational and strategic innovations;

develop special training and professional development programs for managers and staff at the enterprise;

- implement an integrated risk management system that will identify potential threats to innovative projects and develop a set of measures to minimize them.

In conclusion, it should be recalled that the construction sector, due to the relatively long production cycle and the specifics of financial payments for performed work, usually enters a crisis or recession later than other basic economy sectors, but, unfortunately, later than others and more painfully comes out of this state. The primary role in overcoming the crisis phenomena belongs to innovations, innovative activities that will ensure dynamically stable economic development, continuous updating of the technical and technological base of production, development and production of new competitive products, access to world markets of goods and services.

\section{References}

1. S. Domnina, E. Savoskina,N. Shekhova On innovative decisions in the investment-construction cycle. Procedia Engineering, 153, 741-746 (2016) DOI: 10.1016/j.proeng.2016.08.236

2. V. KankhvaRisk management in the implementation of smart building projects. MATEC Web Conf., 106, 08027(2017) DOI: $10.1051 /$ matecconf/201710608027V

3. S. Korol Innovative development of the construction industry as an economic category of the control object. Regional economy and management: electronic scientific journal 14501 (2016)

4. W. Shou, J. Wang, X. Wang, et al. A comparative review of building information modelling implementation in building and infrastructure industries. Arch. Computat. Methods. Eng., 22, 291-308 (2015) DOI: 10.1007/s11831-014-9125-9

5. E.Chirkunova, E.Kireeva, A.Kornilova,Y, Pshenichnikova Research of instruments for financing of innovation and investment construction projects.Procedia Engineering, 153, 112-117 (2016) DOI: doi.org/10.1016/j.proeng.2016.08.089

6. A. Solovyev, A. Pustovgar, L. Shilova, A. Adamtsevich, D.SolovevSimulating power efficiency of heat transfer agent cooling recirculation systems at power plants. ProcediaEngineering, 165, 1275-1280 (2016)DOI:10.1016/j.proeng.2016.11.850

7. V. Rozhkov, D. Zainullina A critical analysis of the prospects for innovative development of the construction industry in the Republic of Tatarstan // Russian Journal of Entrepreneurship. 17, 29112922. (2016) DOI: 10.18334 / rp.17.21.36934

8. HighschoolofEconomics Business climate in construction in the first quarter of 2020. Moscow: HSE.URL: https://issek.hse.ru/mirror/pubs/share/357527741.pd f.

9. I. Ilin, O. Kalinina, O. Iliashenko, A.LevinaITarchitecture reengineering as a prerequisite for sustainable development in Saint Petersburg urban underground. Procedia Engineering,165, 1683- 1692 (2016) DOI: 10.1016/j.proeng.2016.11.910

10. A. Kornilova, E. Acri, N. Pronina Automation of design and technological preparation of repair works. In: Ashmarina S., Mantulenko V. (Eds.), Current Achievements, Challenges and Digital Chances of Knowledge Based Economy. Lecture Notes in Networks and Systems, 133(pp. 347-351). 
Cham:Springer (2021)DOI: doi.org/10.1007/978-3030-47458-4_41

11. D. Paredes, M. The net benefit of demolishing dilapidated housing: The case of Detroit. Regional science and urban economics,66, 16-27 (2017)

12. H.-Y. Chong, X.Wang The outlook of building information modeling for sustainable development. Clean Technologies and Environmental Policy, 18, 1877-1887(2016)

13. Nuvolari A. Collective invention during the British Industrial Revolution: the case of the Cornish pumping engine // Cambridge Journal of Economics. Vol. 28 № 3 P. 347-363 (2004)

14. Douthwaite B., Keatinge J.D.H., Park J.R. Why promising technologies fail: the neglected role of user innovation during adoption // Research Policy. Vol. 30 P. 819-836 (2001)

15. Harhoff D., Joachin H., von Hippel E. Profiting from voluntary information spillovers: how users benefit from freely revealing their innovations // Research Policy. Vol. 32 № 10 P. 1753-1769 (2003)

16. Barbaroux P. On the Nature and Logics of Innovation Capabilities within Knowledge-Intensive Environments: A Case Study // Journal of Innovation Economics. Vol. 1 № 3 P. 169-188 (2009)

17. Jin C., von Hippel E. The major shift towards usercentered innovation. Implications for China's innovation policymaking // Journal of KnowledgeBased Innovation in China. Vol. 32 № 1 P. 16-27 (2009)

18. Franke N., Shah S. How communities support innovative activities: an exploration of assistance and sharing among end-users // Research Policy. Vol. 32 P. 157-178 (2003)

19. Calvignac C. Socio-économie d'une innovation par l'usager. Les réseaux wifi-communautaires // Réseaux (148-149). P. 200-34 (2008).

20. Morrison P.D., Roberts J.H., von Hippel E. Determinants of user innovation and innovation sharing in a local market // Management Science. Vol. 46 № 12 P. 1513-1527 (2000) . 